\title{
RESEARCH ARTICLE \\ Nutrient Composition, Antioxidant and Antibacterial Activities of Ulva prolifera O. F. Müller
}

Eldrin DLR. Arguelles ${ }^{1 *}$ and Arsenia B. Sapin ${ }^{2}$

Philippine National Collection of
Microorganisms, National Institute of Molecular
Biology and Biotechnology (BIOTECH),
University of the Philippines Los Baños,
Philippines 4031
'Food Laboratory, National Institute of
Molecular Biology and Biotechnology
(BIOTECH), University of the Philippines Los
Baños, Philippines 4031
* Corresponding Author:
eda.biotech@gmail.com;
edarguelles@up.edu.ph
Received: 5 May 2021
Accepted: 18 August 2021
Published: 17 December 2021
oSqualen Bulletin of Marine and Fisheries
Postharvest and Biotechnology, 2021.
Accreditation Number: $148 / \mathrm{M} / \mathrm{KPT} / 2020$.
ISSN: $2089-5690$, e-ISSN: 2406-9272.
doi: 10.15578/squalen.550

\begin{abstract}
Seaweeds are marine organisms capable of producing diverse kinds of chemical compounds with promising pharmacological use. The study evaluated the proximate and elemental composition and the potential antioxidant (using CUPRAC, $\mathrm{ABTS}^{+}$, and DPPH assays) and antibacterial activities (using microtiter plate dilution assay) of Ulva prolifera $\mathrm{O}$. F. Müller. The seaweed has a total phenolic content of $829 \pm 2.00 \mathrm{mg} \mathrm{GAE} / \mathrm{g}$. Antioxidant efficiency of $U$. prolifera exerted high ability of reducing copper ions, potent $\mathrm{ABTS}^{+}$and DPPH scavenging activities in a concentration-dependent manner with $\mathrm{IC}_{50}$ value of $24.7 \mathrm{mg} \mathrm{GAE} / \mathrm{mL}, 43.52 \mathrm{mg} \mathrm{GAE} / \mathrm{mL}$, and $54.1 \mathrm{mg} \mathrm{GAE} / \mathrm{mL}$, respectively, more effective than ascorbic acid. In vitro antibacterial activity assay showed that $U$. prolifera exhibited inhibitory activity against bacterial pathogens such as Methicillin-resistant Staphylococcus aureus (MIC $=125 \mathrm{mg} / \mathrm{mL}$ ), S. epidermidis $(\mathrm{MIC}=125 \mathrm{mg} / \mathrm{mL})$, and Pseudomonas fluorescens $(\mathrm{MIC}=500 \mathrm{mg} / \mathrm{mL})$. This investigation is the first documented report regarding antibacterial activity of $U$. prolifera against $P$. fluorescens. In addition, results showed elemental composition to be in decreasing order of $\mathrm{Ca}>\mathrm{K}>\mathrm{Mg}>\mathrm{Na}>\mathrm{Mn}>\mathrm{Fe}>\mathrm{Zn}>\mathrm{Cu}$ $>\mathrm{Pb}>\mathrm{Cd}>\mathrm{Cr}$. Proximate composition of $U$. prolifera showed high carbohydrate and protein content with a percentage composition of $36.20 \pm 0.27 \%$ and 23.72 $\pm 0.31 \%$ (dry weight), respectively. This study is the first report in the Philippines that shows the potential of $U$. prolifera as an excellent candidate organism as source of chemical compounds with relevant application to the pharmacological industry.
\end{abstract}

Keywords: antioxidant activity, nutritional composition, phenolic content, polyphenols, seaweed

\section{Introduction}

The demand of human society for a healty lifestyle and increased longevity has led people (consumers) to consume functional foods with plentiful sources of chemical compounds and other nutraceuticals. Of these well-known natural foods, seaweeds are considered as one of the most valuable natural resources for macronutrients (carbohydrates, proteins and lipids), micronutrients (vitamins and minerals), and other significant chemical substances for animal and human health (Corsetto et al., 2020; Cotas et al., 2020; Arguelles, Monsalud, \& Sapin, 2019; Arguelles, Laurena, Monsalud, \& Martinez-Goss, 2018; Sivaramakrishnan et al., 2017). Recent studies shows that several unique compounds from seaweeds, such as acrylic acid, brominated phenols, heterocyclic carbons, polysaccharides, terpenes, peptides, chlorophyllides and sterols, were isolated and being developed as new active ingredients for pharmaceuticals (Cotas et al., 2020; Yuan et al., 2018; Yaich et al., 2011). These substances have diverse biological and chemical activities like antimicrobial, anticancer, anti-diabetic, anti-inflammatory, antioxidant and anti-hypertensive properties that can be used to discover novel drugs for pharmaceutical application (Kordjazi, Etemadian, Shabanpour, \& Pourashouri, 2019; Sivaramakrishnan et al., 2017).

Macroalgae are also regarded as popular food ingredients and are widely consumed in several countries. However, the nutritional profiles of these organisms have not been fully elucidated since only a few studies on the nutritional composition of seaweeds have been conducted (Arguelles et al., 2019). Edible seaweeds abound insoluble proteins, dietary fibers or 
carbohydrates, minerals, polyunsaturated fatty acids, and vitamins (Wells et al., 2017; Senapati et al., 2016). Several studies reported that the protein concentration of dried seaweed biomass differs from 30-40\% (Rhodophyta) to around 5-10\% (Phaeophyta) both of which have low lipid content, $1-5 \%$ of the dry weight algal biomass. Also, these organisms are an excellent alternative source of minerals $(36 \%$ of its total dry biomass) and high fiber content (3- 50\% of total dry biomass) (Senapati et al., 2016; Wells et al., 2017; Matanjun, Mohamed, Mustapha, \& Muhammad, 2008). The biochemical compositions of seaweeds vary in different species. These variations are caused by several factors such as seasonal changes, environmental factors (salinity, minerals, water temperature, nutrients, and light), and geographical differences (Haq et al., 2019; Wells et al., 2017; Yaich et al., 2011). The genus Ulva (Chlorophyta) has high carbohydrates, proteins, dietary fiber, vitamins, and minerals, making this group of seaweeds a significant natural food source for commercial production. These macroalgae are also being tapped as potential value-added food because of reported health benefits such as therapeutic bioactive peptides and prebiotics (dietary fiber) source as well as other functional properties such as anti-diabetic, antimicrobial, and antioxidant activities (Manandhar et al., 2019; Arguelles et al., 2018; Wells et al., 2017; Yuan et al., 2018).

Seaweeds are renewable natural resources that grow abundantly in different coastal areas (islands and reefs) of the Philippines. U. prolifera O. F. Müller is a green seaweed that is classified to the order Ulvales and family Ulvaceae. It is a bloom-forming algae usually associated with the occurrence of the green tide phenomenon in some coastal areas of the Philippines. Previously, this seaweed was reported to have bioactive compounds such as polyphenols, peptides, chlorophyll, and carotenoids. These compounds exhibit important chemical properties useful for nutraceutical, pharmacological industry, and functional food for humans (Corsetto et al., 2020; Cotas et al., 2020; Haq et al., 2019; Arguelles et al., 2018; Zhao, Yang \& Liu, 2016). U. prolifera is edible and is considered an economically viable food option in Japan and China. The algae is nutritious and regarded as low-calorie food rich in essential amino acids, fatty acids, vitamins, dietary fiber, and proteins. It also contains chlorophyll $b$ and different minerals, such as calcium, magnesium, and iron. Polysaccharides are the major component of $U$. prolifera. The use of these carbohydrate polymers expands from food and pharmaceutical industries (Haq et al., 2019; Zhao, Yang, \& Liu, 2016). This investigation is the first documented report in the Philippines showing the bioactive properties of a green tide-causing macroalga, $U$. prolifera, with potential use as natural antioxidants, control of bacterial diseases and as an alternative source of minerals for nutraceutical application. The study was conducted to evaluate the proximate and elemental composition of the dried algal biomass. In addition, the total polyphenolic content (TPC), antibacterial and antioxidant (using copper reduction antioxidant capacity (CUPRAC), 2,2'-Azinobis (3-ethylbenzothiazoline-6-sulfonic acid) $\left(\mathrm{ABTS}^{+}\right)$, and 2,2-diphenyl-1-picrylhydrazyl (DPPH) radical scavenging assays) activities of $U$. prolifera were analyzed. Furthermore, correlation analysis between phenolic concentration and antioxidant property of the seaweed extract was established.

\section{Material and Methods}

\section{Chemicals}

The chemicals used were of analytical grade and obtained from Sigma-Aldrich (Steinheim, Germany), Sigma-Aldrich (Singapore City, Singapore) or SigmaAldrich (St. Louis, MO, USA). Meanwhile, the solvents used were of HPLC grade and analytical grade and obtained from Sigma-Aldrich (Steinheim, Germany, St. Louis, MO, USA and Singapore City, Singapore) or Merck (Darmstadt, Germany).

\section{Seaweed Sampling and Preparation}

The green macroalga, U. prolifera, was gathered on January $18^{\text {th }}$, 2020 during low tide conditions alongside the coast of Pagkalitan (Lat. $13^{\circ} 38^{\prime} 4.2^{\prime \prime} \mathrm{N}$; Long. $121^{\circ} 2^{\prime} 39^{\prime \prime}$ E), Batangas, Philippines. The collected sample was initially cleaned with seawater to remove sand debris and other loosely attached organisms. The seaweed was immediately transferred to the laboratory using sterilized polythene bags kept in a cooler with ice. The macroalga was washed several times with distilled water and scrubbed thoroughly using brush bristles to remove the seaweed's epiphytes, sand particles, and necrotic parts. $U$. prolifera was air-dried under direct sunlight for six days and pulverized (using a dry grinder) before extraction (Arguelles et al., 2019). The pulverized samples were sieved to get the uniform size of seaweed particles, then placed in an air-tight glass container and kept in a freezer ( set at $-20^{\circ} \mathrm{C}$ ) until the needed chemical assays were conducted. The seaweed was identified using morphological characteristics and identification keys of Trono (1997) and Algae Base (web site: www.algaebase.org) (Guiry \& Guiry, 2020).

\section{Preparation of Seaweed Extract}

The powdered $U$. prolifera $(1 \mathrm{~g})$ was extracted with $30 \mathrm{~mL}$ acidified methanol $\left(1 \mathrm{HCl}: 80 \mathrm{CH}_{3} \mathrm{OH}: 10\right.$ 
$\mathrm{H}_{2} \mathrm{O}$ ) in an ultrasonic bath for $30 \mathrm{~min}$ and stirred for 1 h. The extraction mixture was centrifuged for $20 \mathrm{~min}$ at a speed of $12,000 \mathrm{rpm}$ at $20^{\circ} \mathrm{C}$. U . prolifera extract was concentrated under reduced pressure set at $40{ }^{\circ} \mathrm{C}$ using a rotary evaporator. The concentrated extract was kept at $4{ }^{\circ} \mathrm{C}$ to maintain its activity in other biological/chemical assays needed in the study (Arguelles, 2021).

\section{Proximate Composition Analysis}

$U$. prolifera biomass was dried for $24 \mathrm{~h}$ at $60{ }^{\circ} \mathrm{C}$ and then grind into a powder prior to proximate composition analysis using standard methods. The ash, protein $(\mathrm{N} \times 4.38)$, crude fiber, and fat contents were determined using protocols set by the AOAC (2011). The total carbohydrate content was obtained via the difference method following the equation below:

$\%$ Carbohydrates $=100-(\%$ Moisture Content $+\%$ Protein $+\%$ Fat $+\%$ Ash $)$

\section{Elemental Composition Analysis}

The powdered biomass of $U$. prolifera was subjected to elemental composition analysis using the standard protocols (AOAC, 2011). The analysis was done to detect and quantify magnesium $(\mathrm{Mg})$, cadmium $(\mathrm{Cd})$, potassium $(\mathrm{K})$, chromium $(\mathrm{Cr})$, calcium $(\mathrm{Ca})$, zinc $(\mathrm{Zn})$, manganese $(\mathrm{Mn})$, iron $(\mathrm{Fe})$,sodium $(\mathrm{Na})$, copper $(\mathrm{Cu})$, and lead $(\mathrm{Pb})$ using an Atomic Absorption Spectrophotometer Perkin Elmer AAnalyst 400.

\section{Determination of Total Phenolic Content (TPC)}

The TPC of $U$. prolifera extract was assessed following the Folin-Ciocalteu procedure of Nuñez Selles et al. (2002). Briefly, $0.5 \mathrm{~mL}$ of $U$. prolifera extract was thoroughly mixed in equal volume with $10 \%$ sodium carbonate solution and Folin-Ciocalteau's reagent for $1 \mathrm{~min}$. The mixture was then kept at ambient temperature for about $5 \mathrm{~min}$. The reaction mixture's final volume was increased to $5 \mathrm{~mL}$ using sterile water. The reaction mixture's optical density reading (OD) was noted at $720 \mathrm{~nm}$ using an Ultraviolet-Visible spectrophotometer. The TPC is presented as a microgram of gallic acid equivalent (GAE) per gram of the algal sample (standard curve equation: $\mathrm{y}=$ $\left.0.0682 \mathrm{x}-0.0214, \mathrm{r}^{2}=0.997\right)$.

\section{Antioxidant Activities}

Polyphenolic compounds from seaweeds are known to have diverse antioxidant and biological activities. The antioxidant properties of $U$. prolifera extract were determined using radical scavenging assays for DPPH, $\mathrm{ABTS}^{+}$and CUPRAC assays. Three methods of antioxidant assays were used in the investigation to elucidate the different mechanisms responsible for the antioxidant activities of $U$. prolifera extract.

\section{ABTS $^{+}$(2,2'-Azino-bis (3-ethylbenzo- thiazoline-6-sulfonic acid) Scavenging Assay}

The potential of $U$. prolifera extract to scavenge $\mathrm{ABTS}^{+}$free radical was determined using a method based on the decolorization of $\mathrm{ABTS}^{+}$(Re et al., 1999). In this assay, radical cations $\left(\mathrm{ABTS}^{+}\right)$are generated by the reaction of sodium persulfate (bluish) and $\mathrm{ABTS}^{+}$. These radical cations are reactive in several antioxidants (including polyphenols) and convert the $\mathrm{ABTS}^{+}$to its neutral (colorless) form. An aliquot (40 $\mu \mathrm{L})$ of different prepared concentrations of $U$. prolifera extract (12.5-62.5 $\mu \mathrm{g} \mathrm{GAE} / \mathrm{mL})$ and $40 \mu \mathrm{L}$ of $90 \%$ methanol (for the control) were homogenized with $3 \mathrm{~mL}$ of $\mathrm{ABTS}^{+}$radical mixture (with initial OD reading of $0.72 \pm 0.05$ at $734 \mathrm{~nm}$ ). The solutions were thoroughly mixed and kept at ambient temperature for 5 min. The absorbance reading of each sample was noted at $734 \mathrm{~nm}$ using water to zero the spectrophotometer (Re et al., 1999). The ABTS ${ }^{+}$ inhibition (\%) was estimated using the following formula:

$$
\operatorname{ABTS} \text { Inhibition }(\%)=\left(\frac{A_{\text {control }}-A_{\text {sample }}}{A_{\text {control }}}\right) \times 100
$$

The percentage of $\mathrm{ABTS}^{+}$inhibition (\%) was marked against separately prepared concentrations of $U$. prolifera extract. The prepared concentration of the seaweed extract that exhibited 50\% ABTS radical scavenging activity was considered as the $\mathrm{IC}_{50}$. The standard antioxidant used in this assay is ascorbic acid $\left(\mathrm{IC}_{50}=147.9 \mu \mathrm{g} / \mathrm{mL}\right)$.

\section{2,2-diphenyl-1-picrylhydrazyl (DPPH) Radical Scavenging Assay}

The scavenging activity of $U$. prolifera extract against DPPH free radical was analyzed following the protocol done by Ribeiro, Barbosa, Queiroz, Knodler, and Schieber (2008). Briefly, $100 \mu \mathrm{L}$ of the $U$. prolifera extract $(10.0-50.0 \mu \mathrm{g} \mathrm{GAE} / \mathrm{mL})$ was added into 5.0 $\mathrm{mL}$ of $0.1 \mathrm{mM}$ DPPH methanolic solution. It was then homogenized using a vortex mixer and set aside for 20 min at ambient temperature. The optical density (OD) readings of the $U$. prolifera extract and the controls were noted at $517 \mathrm{~nm}$ using a UV-VIS spectrophotometer. The percent DPPH radical scavenging inhibition (\%) was estimated using the following formula:

$$
\text { DPPH Inhibition }(\%)=\left(\frac{A_{\text {control }}-A_{\text {sample }}}{A_{\text {control }}}\right) \times 100
$$


where: $\mathrm{A}_{\text {control }}=$ optical density of the control (DPPH solution without algal extract) and $\mathrm{A}_{\text {sample }}=$ optical density of the algal sample (DPPH solution plus algal extract). Gallic acid was used as the control in this assay. The effective concentrations $\left(\mathrm{IC}_{50}\right)$ of the $U$. prolifera extract, as well as the control needed to neutralize $50 \%$ of DPPH free radicals, were analyzed using the standard curve obtained from scavenging capacities and various concentrations of algal extract and is expressed in $\mu \mathrm{g} / \mathrm{mL}$ (Arguelles et al., 2019).

\section{Copper Reduction Antioxidant Capacity (CUPRAC) Assay}

The antioxidant activity of $U$. prolifera extract $(5.0$ $-25.0 \mu \mathrm{g} \mathrm{GAE} / \mathrm{mL})$ to reduce cupric ions $\left(\mathrm{Cu}^{2+}\right)$ was done following the method proposed by Alpinar et al. (2009). In this antioxidant assay, $1 \mathrm{~mL}$ each of $1 \mathrm{M}$ ammonium acetate buffer ( $\mathrm{pH} 7), 0.0075 \mathrm{M}$ neocuproine, and $0.01 \mathrm{M} \mathrm{CuCl}_{2}$ solutions were mixed in prepared sterile test tubes containing $0.5 \mathrm{~mL}$ of $U$. prolifera extract $(5.0,10.0,15.0,20.0$ and $25.0 \mu \mathrm{g}$ $\mathrm{GAE} / \mathrm{mL}$ ) and ascorbic acid as the standard antioxidant (Arguelles, 2021). The total volume for each reaction mixtures prepared was adjusted to $4.1 \mathrm{~mL}$ using sterile distilled water and kept for $30 \mathrm{~min}$ at ambient temperature. The absorbance readings (OD) of $U$. prolifera extract and ascorbic acid concentrations were recorded at $450 \mathrm{~nm}$ (Arguelles, 2021).

\section{Antibacterial Activity}

The National Institute of Molecular Biology and Biotechnology (BIOTECH), University of the Philippines Los Baños (UPLB) provided the test organisms used in this investigation. A total of three Gram-negative bacteria (Aeromonas hydrophila BIOTECH 10089, Escherichia coli BIOTECH 1825, and Pseudomonas fluorescens BIOTECH 1123) and three Gram-positive bacteria (Staphylococcus epidermidis BIOTECH 10098, Methicillin-Resistant Staphylococcus aureus BIOTECH 10378 and Bacillus cereus BIOTECH 1509 ) were tested against $U$. prolifera extract using the microtiter plate dilution assay. The reference bacterial pathogens were pre-cultivated using Luria Bertani (LB) Broth medium and kept at $37{ }^{\circ} \mathrm{C}$ with shaking for $24 \mathrm{~h}$. To maintain the cultures, the purity and viability for each bacterial pathogens are regularly monitored via morphological characterization and biochemical tests every week (Arguelles, 2021).

A two-fold serial dilution technique was used to establish the minimum bactericidal concentration (MBC) and minimum inhibitory concentration (MIC) of $U$. prolifera extract (Arguelles, 2021). Briefly, $100 \mu \mathrm{l}$ of test bacterial pathogens (with a corresponding cell density of $1 \times 10^{6}$ cells $/ \mathrm{mL}$ ) were combined with 100 $\mu \mathrm{L}$ of $U$. prolifera extract set in different dilutions (1000 $\mu \mathrm{g} / \mathrm{mL}-7.8125 \mu \mathrm{g} / \mathrm{mL})$. The antibacterial assay was done in triplicate using a 96-well microtiter plate and kept for $12 \mathrm{~h}$ in an incubator set at $35^{\circ} \mathrm{C}$. After incubation, MICs of $U$. prolifera extract, as opposed to the tested bacterial pathogens, were noted. Streptomycin was used as the positive control against the tested pathogenic bacteria. Minimum bactericidal concentration (MBC) was determined following the protocol done by Arguelles (2021) with few modifications. Loopful of samples in microtiter plate wells that exhibited no bacterial growth from the MIC assay were inoculated onto tryptic soy agar plates and were kept at $35^{\circ} \mathrm{C}$ for $24 \mathrm{~h}$. After incubation, the petri plates were evaluated for bacterial colony growth for each dilution subculturing. The absence of colony growth would mean that $U$. prolifera extract was bactericidal at that specific dilution (Arguelles, 2021).

\section{Statistical Analyses}

The experimental data are presented as means \pm standard deviations (mean \pm SD) of three assay replicates. The statistical tests for the linear correlation coefficient necessary for the correlation analysis were analyzed using MS Office Excel 2007.

\section{Results and Discussion}

\section{Proximate Composition Analysis}

Algae are valuable sources of micronutrients such as vitamins and minerals and macronutrients such as carbohydrates, protein, lipids, and fiber, directly relevant to human health (Arguelles \& Martinez-Goss, 2021; Arguelles et al., 2018; Osuna-Ruiz et al., 2019). These organisms are considered good alternative nutrient sources of protein, lipids and carbohydrates that can enrich the traditional plant-based sources for human consumption (Ismail, 2017). Seaweeds are good alternative sources of proteins and lipids that can be used in animal feed formulation and the development of highly nutritious foods that can replace current crop protein sources (such as bean) consumed by humans. These organisms can enhance the nutritional quality of human foods and animal feeds while at the same time reducing the cost of production. In addition, seaweed-based food and feeds also improve humans' immunity and overall health using bioactive polysaccharides and other important chemical constituents that possess important biological activities such as antibacterial, anti-inflammatory, and antiviral activities. Seaweeds are also considered alternative sources of important microelements because of the high concentration of minerals in the algal biomass. These micronutrients can be utilized by humans and 
other animals as food additives for food and industrial applications (Arguelles \& Martinez-Goss, 2021; Alwaleed, 2019; D'Armas, Jaramillo, D'Armas, Echavarría, \& Valverde, 2019). The proximate composition of $U$. prolifera is presented in Table 1 . The seaweed contains a high carbohydrate, protein, and lipid concentration with a percent composition of $36.20 \pm 0.27 \%$ and $23.72 \pm 0.31 \%, 12.50 \pm 0.11 \%$, respectively. Such results prove that $U$. prolifera is a good source of carbohydrate, protein, and lipids that can be utilized as a functional food for humans. Carbohydrate content of $U$. prolifera is less than those obtained from other seaweed species (dry biomass) such as Sargassum polycystum (90.01\%), Digenea simplex $(42.40 \%)$ and Cystoseira myrica $(78.7 \%)$ (Alwaleed, 2019). On the other hand, the crude fat content of $U$. prolifera is higher than those obtained by Raja et al. (2020) from Gracilaria corticota and Halimeda opuntia with a percent composition of 10.09 $\pm 0.06 \%$ and $7.26 \pm 0.048 \%$, respectively. Differences in lipid and carbohydrate contents among seaweeds can be due to factors like the effects of climate and geography on the development and growth of seaweeds (Ismail, 2017; Matanjun et al., 2008). The crude protein content of $U$. prolifera is greater than those obtained by Osuna-Ruiz et al. (2019) from tropical seaweeds of Sinaloa, Mexico which includes Urera expansa $(4.12 \pm 0.51 \%)$, Caulerpa sertularioides $(11.96 \pm 1.93 \%)$, Codium isabelae $(8.90 \pm 0.06 \%)$, Rhizoclonium riparium $(7.85 \pm 0.90 \%)$, Spyridia lamentosa (10.61 $\pm 0.34 \%), \quad$ Gracilaria vermiculophylla $(10.15 \pm 0.50 \%)$ and Padina durvillaei $(5.87 \pm 0.12 \%)$. Variations in the protein content among different groups and species of seaweeds are caused by differences in the nitrogen levels present on the algal tissue that is highly dependent on the concentration of nutrients (nitrogen) in seawater (D’Armas et al., 2019).

Table 1. Proximate composition of $U$. prolifera dry biomass.

\begin{tabular}{lc}
\hline Proximate composition & Percent composition (\%) \\
\hline Moisture Content & $4.66 \pm 0.20$ \\
Ash Content & $15.89 \pm 0.04$ \\
Crude Protein & $23.72 \pm 0.31$ \\
Crude Fat & $12.50 \pm 0.11$ \\
Crude Fiber & $6.03 \pm 0.15$ \\
Carbohydrate & $36.20 \pm 0.27$ \\
\hline
\end{tabular}

Table 1 showed other dominant biochemical components like ash $(15.89 \pm 0.04 \%)$ and crude fiber $(6.03 \pm 0.15 \%)$. The ash content shows the concentration of inorganic substances in seaweeds.
This parameter is influenced by the existing minerals and salt attached to the macroalgae. U. prolifera are rich in minerals which are beneficial for feed formulation in animals. On the other hand, crude fiber represents the concentration of indigestible components of the macroalgae. In this study, low concentration of crude fiber was observed in $U$. prolifera and is comparable to that obtained by D'Armas et al. (2019) from other species of seaweeds such as Kappaphychus alvarezii $(3.18 \pm 0.11 \%)$, Padina pavonica $(4.94 \pm$ $0.16 \%)$, Ulva lactuca $(0.96 \pm 0.03)$, Centroceras clavulatum (2.02 $\pm 0.11 \%)$, and Acanthophora spicifera $(2.42 \pm 0.24 \%)$.

\section{Elemental Composition Analysis}

Essential minerals for human consumption include sulfur, potassium, phosphorus, sodium chloride (salt), calcium, iron, manganese, and magnesium. Also, trace elements such as copper, cobalt, iodine, zinc, molybdenum, and selenium are essential but should be consumed by humans in regulation and not in excessive amounts (Arguelles, 2021; D' Armas et al., 2019; Matanjun et al., 2008). The result of the elemental composition analysis of $U$. prolifera is shown in Table 2. The elemental distribution in $U$. prolifera was observed to be in decreasing order of $\mathrm{Ca}>\mathrm{K}>\mathrm{Mg}>$ $\mathrm{Na}>\mathrm{Mn}>\mathrm{Fe}>\mathrm{Zn}>\mathrm{Cu}>\mathrm{Pb}>\mathrm{Cd}>\mathrm{Cr}$. High concentration of calcium $(\mathrm{Ca})(20,181.10 \pm 32.91 \mathrm{ppm})$ followed by magnesium $(\mathrm{Mg})(14,981 \pm 365 \mathrm{ppm})$, sodium $(\mathrm{Na}) \quad(9,863 \pm 0.17 \mathrm{ppm})$, and manganese (Mn) $(533.47 \pm 2.77 \mathrm{ppm})$ were observed in the seaweed biomass. The high concentration of these elements in $U$. prolifera biomass is comparable to that observed by Akköz, Arslan, Unver, Özcan, and Yilmaz (2011) in Enteromorpha intestinalis (a green seaweed) for calcium $(\mathrm{Ca})(22,818.99 \pm 42.38 \mathrm{ppm})$, magnesium (mg) $(15,764 \pm 132.36 \mathrm{ppm}), \operatorname{sodium}(\mathrm{Na})(8,690.27$ $\pm 69.38 \mathrm{ppm})$, and manganese $(\mathrm{Mn})(691.33 \pm 11.32$ ppm). This study demonstrates that $U$. prolifera can be used as an alternative source of important microelements (for human use) because of the high concentration of essential minerals present in the algal biomass. In addition, low concentration of other trace elements such as iron (Fe) (251.91 $\pm 0.25 \mathrm{ppm})$, copper $(\mathrm{Cu})(16.57 \pm 0.18 \mathrm{ppm})$, zinc $(\mathrm{Zn})(18.15 \pm 0.45$ ppm), chromium $(\mathrm{Cr})(1.74 \pm 0.13 \mathrm{ppm})$, lead $(\mathrm{Pb})$ $(1.37 \pm 0.25 \mathrm{ppm})$, and cadmium $(\mathrm{Cd})(1.01 \pm 0.14$ ppm) was observed from the algal biomass. Such observation can be used to indicate the low occurrence of heavy metal pollution in the sampling area. This concentration level in $U$. prolifera biomass is favorable for human consumption since these elements are only required in minimal concentrations (D'Armas et al., 2019; Alfonso et al., 2018). 
Table 2. Concentrations of macro and micro-elements ( $\mathrm{ppm}$ ) of U. prolifera O.F. Müller

\begin{tabular}{|c|c|c|c|c|c|c|c|c|c|c|c|}
\hline \multirow{2}{*}{ Seaweed } & \multicolumn{11}{|c|}{ Elemental Parameter* (ppm) } \\
\hline & $\mathrm{Ca}$ & $\mathrm{Mg}$ & $\mathrm{Na}$ & Mn & $\mathbf{K}$ & $\mathrm{Fe}$ & $\mathbf{Z n}$ & $\mathrm{Cu}$ & $\mathrm{Pb}$ & $\mathrm{Cr}$ & $\mathrm{Cd}$ \\
\hline $\begin{array}{l}\text { Ulva } \\
\text { prolifera }\end{array}$ & $22,818.99 \pm 42.38$ & $15,764 \pm 132.36$ & $9,863 \pm 0.17$ & $533.47 \pm 2.77$ & $13,989 \pm 1,188$ & $251.91 \pm 0.25$ & $18.15 \pm 0.45$ & $16.57 \pm 0.18$ & $1.37 \pm 0.25$ & $1.74 \pm 0.13$ & $1.01 \pm 0.14$ \\
\hline
\end{tabular}

* All values are reported as mean \pm standard deviation $(n=3)$

Normally, the elemental composition of green macroalgae has high levels of $\mathrm{Mg}, \mathrm{K}, \mathrm{Na}$, and $\mathrm{Ca}$, with reported concentrations greater than those obtained from other groups of seaweed (Alfonso et al., 2018; Akköz et al. 2011). Also, previous study observed that green seaweeds such as $U$. lactuca are also rich in $\mathrm{Fe}$ with an estimated concentration of $41 \mathrm{mg} / 100 \mathrm{~g}$ or 410 ppm (Yaich et al., 2011). These observations are in accordance with what was observed in the current study regarding the elemental composition of $U$. prolifera. Variations in the concentration of elemental composition from within species and strains of the same seaweed group usually occur depending on the environment where the seaweed is exposed. Seaweeds are capable of bio-accumulating elements from their surrounding environment. Thus, concentration of elements in the seaweed tissue may be controlled by the quality and concentration of the elements present in seawater (Alfonso et al., 2018).

\section{Total Phenolic Content (TPC)}

The TPC of $U$. prolifera extract was analyzed using the Folin-Ciocalteu reagent and reported as gallic acid equivalents (standard calibration curve used has an equation of $\left.y=0.0682 x-0.0214, r^{2}=0.997\right)$. The TPC of the seaweed extracts is $829 \pm 2.00 \mu \mathrm{g} \mathrm{GAE} / \mathrm{g}$. The concentration of polyphenolic compounds observed in this study is greater than that obtained by Akköz et al. (2011) from ethanol extracts of $E$. intestinalis and Cladophora glomerata with $32 \pm 0.003$ $\mu \mathrm{g} \mathrm{GAE} / \mathrm{g}$ and $47 \pm 0.001 \mu \mathrm{g} \mathrm{GAE} / \mathrm{g}$, respectively. Also, TPC of $U$. prolifera is comparable to those observed by Nunes, Ferraz, Valente, Barreto, and Pinheiro de Carvalho (2017) from other seaweed species such as U. lactuca, Chondrus crispus, Asparagopsis taxiformis, Nemalion elminthoides, and Grateloupia lanceola obtained from Madeira archipelago with TPC content of $556.1 \mu \mathrm{g} \mathrm{GAE} / \mathrm{g}$, $362.8 \mu \mathrm{g} \mathrm{GAE} / \mathrm{g}, 576.3 \mu \mathrm{g} \mathrm{GAE} / \mathrm{g}, 655.2 \mu \mathrm{g} \mathrm{GAE} / \mathrm{g}$, and $257.9 \mu \mathrm{g} \mathrm{GAE} / \mathrm{g}$, respectively. The type of solvent influences the concentration of polyphenolic compounds that can be extracted from a sample. Generally, polar organic solvents, such as acidified methanol, exhibit greater capacity to extract polyphenolic compounds in seaweed samples than water (Arguelles, 2021; Nunes et al., 2017). Also, other factors such as differences in the geographic location of the sampling site, growth stage (of the seaweed), seasonal variation and genetic diversity can cause variation in the concentration of phenolic compounds present in seaweed sample (Mekiniæ et al., 2019; Arguelles et al., 2019; Nunes et al., 2017).

\section{Antioxidant Activities}

The diversity of phenolic compounds in seaweeds and other structural features plays a crucial role in the reaction mechanism by which these macroalgae can exhibit antioxidant properties. In this study, the antioxidant activities of $U$. prolifera extract from Pagkalitan, Batangas were analyzed using three methods: DPPH and $\mathrm{ABTS}^{+}$radical scavenging assays as well as CUPRAC assay. These antioxidant assays were used in this study to understand better the mechanisms involved in $U$. prolifera antioxidant activities. Previous study has also documented the antioxidant activities of several strains of Philippine seaweeds (Arguelles, 2021; Arguelles et al., 2019); however, this study documented the first report on the antioxidant activities of $U$. prolifera found in the coastal areas of Pagkalitan, Batangas in the Philippines.

\section{ABTS $^{+}$(2,2'-Azino-bis (3-ethylbenzo-thia- zoline-6-sulfonic acid) Scavenging Activity}

$\mathrm{ABTS}^{+}$antioxidant assay is an excellent method in determining the antioxidant property of chain-breaking antioxidants (lipid peroxyl radical scavenger) and natural antioxidants capable of hydrogen donation (aqueous phase radical scavenger) (Liu et al., 2018; Sivaramakrishnan et al., 2017). The $\mathrm{ABTS}^{+}$scavenging activity and $\mathrm{IC}_{50}$ value of $U$. prolifera extract is shown in Table 3. $\mathrm{ABTS}^{+}$scavenging activity against $U$. prolifera extract demonstrated that the maximum antioxidant activity was $56.41 \pm 1.32 \%$ at phenolic concentration of $62.50 \mathrm{mg} \mathrm{GAE} / \mathrm{mL}$. Further, the result of the antioxidant assay shows that the scavenging activities of $U$. prolifera extract increased with the concentration of phenolic compounds in the algal extract $(12.5$ - $62.50 \mathrm{ug} \mathrm{GAE} / \mathrm{mL})$. The computed $\mathrm{IC}_{50}$ value of the algal extract is $54.10 \mathrm{ug} / \mathrm{mL}$, which is more potent than that obtained from standard antioxidant, ascorbic acid ( $\left.\mathrm{IC}_{50} 147.9 \mathrm{ug} / \mathrm{mL}\right)$. Lower $\mathrm{IC}_{50}$ concentrations are indicative of high antioxidant activity. In collation with the $\mathrm{IC}_{50}$ of other macroalgae 
Table 3. $\mathrm{ABTS}^{+}$radical scavenging activity and $\mathrm{IC}_{50}$ value of phenolics from $U$. prolifera and ascorbic acid.

\begin{tabular}{cccc}
\hline \multicolumn{2}{c}{ Ulva prolifera } & \multicolumn{2}{c}{ Ascorbic Acid } \\
\hline $\begin{array}{c}\text { Phenolic concentration } \\
(\boldsymbol{\mu g} \mathbf{g} \text { GAE } / \mathbf{m L})\end{array}$ & $\begin{array}{c}\text { ABTS } \\
\text { Inhibition }(\%)\end{array}$ & $\begin{array}{c}\text { Concentration } \\
(\boldsymbol{\mu g} / \mathbf{m L})\end{array}$ & $\begin{array}{c}\text { ABTS } \\
\text { Inhibition }(\%)\end{array}$ \\
\hline 12.5 & $14.70 \pm 0.20$ & 37.5 & $11.70 \pm 1.54$ \\
25.0 & $25.22 \pm 0.06$ & 75.0 & $24.56 \pm 0.62$ \\
37.5 & $35.81 \pm 0.10$ & 112.5 & $36.70 \pm 0.51$ \\
50.0 & $46.90 \pm 0.92$ & 150.0 & $50.87 \pm 0.82$ \\
62.5 & $56.41 \pm 1.32$ & 187.5 & $64.53 \pm 1.64$ \\
IC $_{50} *$ & $\mathbf{5 4 . 1 0} \boldsymbol{\mu g} / \mathbf{m L}$ & $\mathbf{I C}_{50 *}$ & $\mathbf{1 4 7 . 9} \boldsymbol{\mu g} / \mathbf{m L}$ \\
\hline
\end{tabular}

* $\mathrm{IC}_{50}$ is the effective concentration that inhibits the activity of ABTS (2,2-Azino-bis (3-ethylbenzothiazoline-6-sulfonic acid) diammonium salt) cation radical by $50 \%$. Computed by interpolation.

such as Halimeda tuna $\left(\mathrm{IC}_{50} 16.1 \mathrm{ug} / \mathrm{mL}\right)$ and Acetabularia acetabulum ( $\left.\mathrm{IC}_{50} 6.3 \mathrm{ug} / \mathrm{mL}\right), U$. prolifera had a comparatively potent antioxidant activity (Sivaramakrishnan et al., 2017). The results suggested that $U$. prolifera extract may contain phenolic compounds that serve as antioxidants capable of inhibiting oxidation through free radical scavenging activity.

\section{2,2-diphenyl-1-picrylhydrazyl (DPPH) Radical Scavenging Activity}

Polyphenols are capable of scavenging DPPH by electron donation or hydrogen atom provision and transforming it to a colorless product (2, 2-diphenyl1 - hydrazine), causing a decrease in optical density of the sample extract at $517 \mathrm{~nm}$ (Liu et al., 2018; Sivaramakrishnan et al., 2017). As the result obtained in $\mathrm{ABTS}^{+}$antioxidant activity assay, the scavenging activity against DPPH free radical also increased when the concentration of $U$. prolifera extract $(10-50 \mu \mathrm{g} /$ $\mathrm{mL}$ ) increases (Table 4). The $\mathrm{IC}_{50}$ value of the seaweed extract $(43.52 \mu \mathrm{g} / \mathrm{mL})$ exhibited greater antioxidant

Table 4. DPPH free radical scavenging activity and $\mathrm{IC}_{50}$ value of phenolics from $U$. prolifera and ascorbic acid.

\begin{tabular}{cccc}
\hline \multicolumn{2}{c}{ Ulva prolifera } & \multicolumn{2}{c}{ Ascorbic Acid } \\
\hline $\begin{array}{c}\text { Phenolic concentration } \\
(\boldsymbol{\mu g} \mathbf{G A E} / \mathbf{m L})\end{array}$ & $\begin{array}{c}\text { DPPH } \\
\text { Inhibition }(\%)\end{array}$ & $\begin{array}{c}\text { Concentration } \\
(\boldsymbol{\mu g} / \mathbf{m L})\end{array}$ & $\begin{array}{c}\text { DPPH } \\
\text { Inhibition }(\%)\end{array}$ \\
\hline 10.0 & $9.22 \pm 0.00$ & 20.0 & $16.64 \pm 0.00$ \\
20.0 & $19.29 \pm 0.06$ & 40.0 & $34.11 \pm 0.61$ \\
30.0 & $34.88 \pm 0.11$ & 60.0 & $50.34 \pm 0.00$ \\
40.0 & $46.11 \pm 0.23$ & 80.0 & $67.32 \pm 0.61$ \\
50.0 & $57.18 \pm 0.23$ & 100.0 & $83.58 \pm 0.67$ \\
IC50* $^{*}$ & $\mathbf{4 3 . 5 2} \boldsymbol{\mu g} / \mathbf{m L}$ & $\mathbf{I C 5 0 *}$ & $\mathbf{5 9 . 6} \boldsymbol{\mu g} / \mathbf{m L}$ \\
\hline
\end{tabular}

$* \mathrm{IC}_{50}$ is the effective concentration that inhibits DPPH free radical by $50 \%$. Computed by interpolation. activity than that obtained from the control antioxidant, ascorbic acid, with $\mathrm{IC}_{50}$ of $59.6 \mu \mathrm{g} / \mathrm{ml}$. In collation with $\mathrm{IC}_{50}$ of other seaweeds obtained from Nain Village, Manado, North Sulawesi (Indonesia) such as $G$. salicornia $(12.81 \mu \mathrm{g} / \mathrm{mL})$, Halymenia durvilae (14.17 $\mu \mathrm{g} / \mathrm{mL})$, Halimeda macroloba (18.54 $\mu \mathrm{g} / \mathrm{mL})$, Turbinaria decurens $(10.01 \mu \mathrm{g} / \mathrm{mL})$, and Sargassum olygocystum $(15.38 \mu \mathrm{g} / \mathrm{mL})$, U. prolifera had a comparatively less potent DPPH antioxidant activity (Sanger, Rarung, Kaseger, Assa \& Agustin, 2019). Seaweeds' antioxidant activity may be associated with polyphenols such as phloroglucinol, vanillic acids, quinin acids, phenylethanol and dieckol in the $U$. prolifera extract. These active substances are known to have scavenging free radical ability (Grina et al., 2020; Mekiniæ et al., 2019). Also, other biotic and abiotic factors such as strains of the alga and seasonal variation have a significant effect on the synthesis of phenolic compounds and thus affecting the antioxidant properties of the seaweed (Mekiniæ et al., 2019; Yuan et al., 2018; Liu et al., 2018).

\section{Copper Reduction Antioxidant Capacity (CUPRAC)}

CUPRAC assay was used in this study to assess the capacity of $U$. prolifera extract to inhibit oxidation via metal chelation mechanism. In this assay, cupric ions are reduced to become cuprous by an electron released by the action of an antioxidant. The cuprous ion creates a stable complex compound with neocuproine, which exhibits maximum absorbance at $450 \mathrm{~nm}$. The extract of $U$. prolifera exhibited a dosedependent copper ion reduction ability (Table 5). The maximum absorbance of 0.506 was observed at $25 \mu \mathrm{g}$ $\mathrm{GAE} / \mathrm{mL}$ concentration of the algal extract.

On the other hand, ascorbic acid (standard antioxidant) shows an absorbance of 0.542 at $50 \mu \mathrm{g} /$ $\mathrm{mL}$ concentration. The observed trend in this antioxidant

Table 5. Copper reduction antioxidant capacity (CUPRAC) and $\mathrm{IC}_{50}$ value of phenolics from $U$. prolifera and ascorbic acid.

\begin{tabular}{cccc}
\hline \multicolumn{2}{c}{ Ulva prolifera } & \multicolumn{2}{c}{ Ascorbic Acid } \\
\hline $\begin{array}{c}\text { Phenolic } \\
\text { concentration } \\
(\boldsymbol{\mu g ~ G A E} / \mathbf{m L})\end{array}$ & $\begin{array}{c}\text { CUPRAC value } \\
(\text { Absorbance at 450 } \mathbf{~ n m})\end{array}$ & $\begin{array}{c}\text { Concentration } \\
(\boldsymbol{\mu} \mathbf{g} / \mathbf{m L})\end{array}$ & $\begin{array}{c}\text { CUPRAC value } \\
(\text { Absorbance at 450 } \mathbf{~ n m})\end{array}$ \\
\hline 5.00 & $0.15 \pm 0.04$ & 10.00 & $0.11 \pm 0.02$ \\
10.00 & $0.23 \pm 0.01$ & 20.00 & $0.23 \pm 0.07$ \\
15.00 & $0.33 \pm 0.01$ & 30.00 & $0.33 \pm 0.04$ \\
20.00 & $0.42 \pm 0.00$ & 40.00 & $0.43 \pm 0.12$ \\
25.00 & $0.51 \pm 0.01$ & 50.00 & $0.54 \pm 0.11$ \\
$\mathbf{I C 5} \mathbf{0}^{*}$ & $\mathbf{2 4 . 7 0} \boldsymbol{\mu g} / \mathbf{m L}$ & $\mathbf{I C 5 0 *}$ & $\mathbf{4 6 . 3 0} \boldsymbol{\mu g} / \mathbf{m L}$ \\
\hline
\end{tabular}

$* \mathrm{IC}_{50}$ is the effective concentration that gives CUPRAC value of 0.5 absorbance reading at $450 \mathrm{~nm}$. Computed by interpolation. 


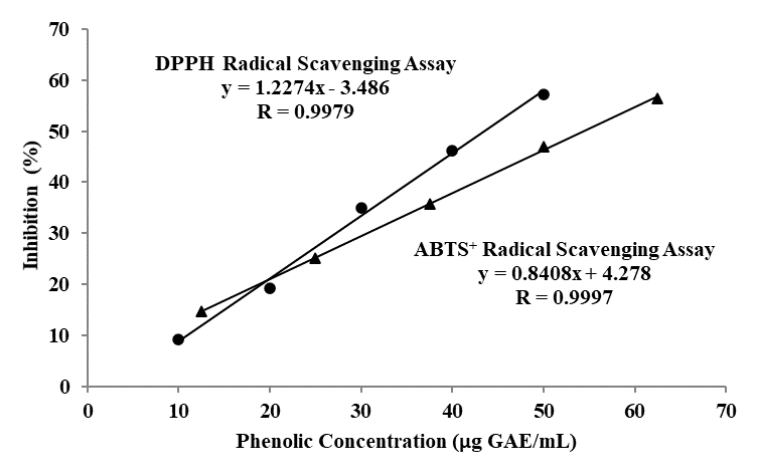

Figure 1. Simple regression correlation between phenolic content and antioxidant activity via $\mathrm{ABTS}^{+}(. \mathbf{-})$ and DPPH (..) radical scavenging assay of $U$. prolifera.

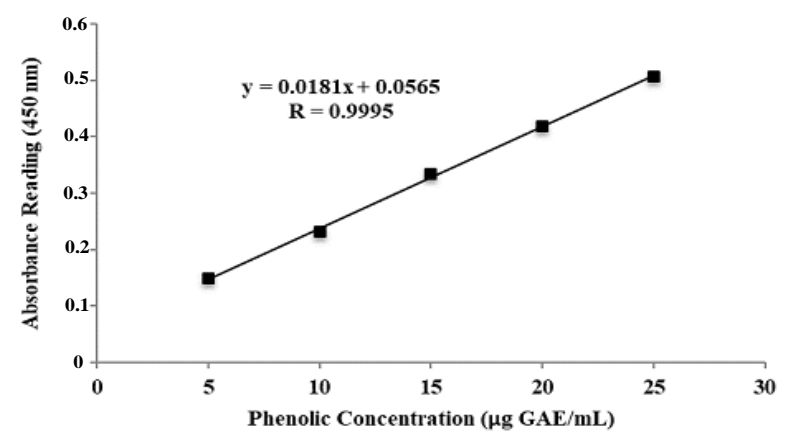

Figure 2. Simple regression correlation between phenolic content and antioxidant activity via copper reduction antioxidant capacity (CUPRAC) assay of $U$. prolifera.

assay is similar to those obtained from the $\mathrm{ABTS}^{+}$and DPPH assay in which $62.5 \mu \mathrm{g} \mathrm{GAE} / \mathrm{mL}$ and $50.0 \mu \mathrm{g}$ $\mathrm{GAE} / \mathrm{mL}$ concentrations exhibited the greatest antioxidant activity. The $\mathrm{IC}_{50}$ value of $U$. prolifera extract is $24.70 \mu \mathrm{g} / \mathrm{mL}$ which is more potent than that obtained from ascorbic acid with $\mathrm{IC}_{50} 46.30 \mu \mathrm{g} / \mathrm{mL}$. This result is relatively comparable to that observed by Gazali, Zamani, and Nurjanah (2019) for Chaetomorpha crassa $\left(\mathrm{IC}_{50}\right.$ value $167.39 \mu \mathrm{mol}$ trolox/ g) from Lhok Bubon, Aceh, Indonesia. The current study proves that $U$. prolifera extract may contain polyphenols that have excellent copper reducing ability as a reaction mechanism of the antioxidant property. These phenolic compounds in $U$. prolifera extract resulted in a potent antioxidant capacity better than ascorbic acid (standard antioxidant) that can be used as an alternative natural antioxidant beneficial for the pharmacological industry.

\section{Correlation Analysis}

The correlation analysis and its corresponding coefficients among different phenolic concentrations and antioxidant properties of $U$. prolifera are presented in Figures 1-2. The algal extract's phenolic content strongly correlated with antioxidant activities using
DPPH, $\mathrm{ABTS}^{+}$and CUPRAC assays with correlation coefficients (R) of 0.9979, 0.9997, and 0.9995, respectively. This finding would mean that the strong antioxidant property of the seaweed extract is caused by polyphenols present in U. prolifera. This correlation is similar to those observed from previous studies from other seaweeds such as Fucus spiralis, S. vulgare, Cystoseira stricta, and Chaetomorpha crasssa on the relationship of phenolic concentration and their antioxidant activities (Grina et al., 2020; Arguelles et al., 2019; Gazali et al., 2019). The significant correlation between antioxidant activity and phenolic concentration suggests that $U$. prolifera extracts can cause oxidation inhibition via metal chelation and free radical scavenging mechanisms. Isolation, identification, and mass production of these active compounds are needed to maximize the potential use of these natural resources for pharmacological studies (Arguelles et al., 2019).

\section{Antibacterial Activity}

Seaweeds have diverse bioactive compounds in response to stress caused by environmental pressure. These compounds, such as polyphenols, terpenes, carotenoids, and alkaloids, possess biological activities that are significant in discovering novel antibiotics needed in the pharmacological industry (Manandhar et al., 2019; Sameeh, Mohamed, \& Elazzazy, 2016). The potential of a green-tide causing species of seaweed, $U$. prolifera, for antimicrobial activity against six pathogenic bacteria was done in this study. The concentrated crude extract of $U$. prolifera was subjected to in vitro antibacterial (microtiter plate dilution) assay against six medically important bacterial pathogens. U. prolifera exhibited an extended spectrum of inhibitory activity against S.epidermidis and Methicillin-Resistant S. aureus (MRSA), each with MIC and MBC values of 125 and $250 \mu \mathrm{g} / \mathrm{mL}$, respectively (Table 6). This result is more potent than that observed for streptomycin (standard antibiotic drug) used in the study against MRSA and S. epidermidis where MIC and MBC values of 250 and $500 \mu \mathrm{g} / \mathrm{mL}$, respectively, were noted. The antibacterial activity of $U$. prolifera against MRSA is comparable to that observed by Sameeh et al. (2016), where ethanol extracts of $P$. boryana (MIC value of $125 \pm 1 \mu \mathrm{g} / \mathrm{mL}$ ) and Enteromorpha sp. (MIC value of $500 \pm 2 \mu \mathrm{g} / \mathrm{mL}$ ) exhibited antimicrobial activities against the bacteria. On the other hand, $U$. prolifera extract is more potent in inhibiting MRSA in collation with other species of brown seaweed such as $P$. boergesenii, $S$. cinereum, and Cystoseira myrica with MIC value of 25, 50 and $50 \mathrm{ug} / \mathrm{mL}$, respectively (El-Sheekh, Mousa, \& Farghl, 2020). Also, $U$. prolifera was able to inhibit Pseudomomas fluorescens showing MIC and MBC values of $500 \mu \mathrm{g} / \mathrm{mL}$ and $1000 \mu \mathrm{g} / \mathrm{mL}$, respectively. A 
Table 6. Antibacterial activities of $U$. prolifera extract

\begin{tabular}{lcc}
\hline \multicolumn{1}{c}{ Bacterial Pathogen } & $\begin{array}{c}\text { Minimum inhibitory } \\
\text { concentration } \\
(\boldsymbol{\mu g} / \mathbf{m L})\end{array}$ & $\begin{array}{c}\text { Minimum } \\
\text { bactericidal } \\
\text { concentration } \\
(\boldsymbol{\mu g} / \mathbf{m L})\end{array}$ \\
\hline \multicolumn{1}{c}{ Gram-positive bacteria } & & \\
\hline $\begin{array}{l}\text { Methicillin-Res istant } \\
\text { Staphylococcus aureus }\end{array}$ & 125.00 & 250.00 \\
BIOTECH 10378 & & \\
Staphylococcus epidermidis & 125.00 & 250.00 \\
BIOTECH 10098 & & \\
Bacillus cereus & $>1000.00$ & $\mathrm{ND}$ \\
BIOTECH 1509 & & 1000.00 \\
\hline Gram-negative bacteria & & \\
\hline Pseudomonas fluorescens & 500.00 & $\mathrm{ND}$ \\
BIOTECH 1123 & & $\mathrm{ND}$ \\
Aeromonas hydrophila & $>1000.00$ & \\
BIOTECH 10089 & & \\
Escherichia coli & & \\
BIOTECH 1634 & & \\
\hline
\end{tabular}

$* \mathrm{ND}=$ None Detected

similar observation was reported by Madkour, ElShoubaky, and Ebada (2019) wherein marine macroalgae such as T. ornata, C. myrica, and Padina pavonica-found on the Red Sea coast of Egypt showed antibacterial activity against Pseudomonas species. However, streptomycin used in the current study was more effective in inhibiting $P$. fluorescens than $U$. prolifera extract, having MIC and MBC values of 125 and $250 \mu \mathrm{g} / \mathrm{mL}$, respectively. On the other hand, no antibacterial activity was observed on $U$. prolifera extract against B. cereus, A. hydrophila and E. coli. The result of this investigation is comparable to earlier studies done by Arguelles et al. (2019) and Jesumani, $\mathrm{Du}$, Pei, Aslam, and Huang (2020). In these investigations, Gram-negative bacteria were less vulnerable to algal extract than to Gram-positive bacteria. This observation is caused by the difference in cell wall composition and structure of Gram-negative bacteria. Gram-negative bacteria contain a thick murine layer and an outer membrane that serve as an added protection and a barrier that inhibits substances such as antibiotics (Kordjazi et al., 2019; Manandhar et al., 2019; Mekiniæ et al., 2019).

The Philippine coast is known to have several species of seaweeds with diverse biological properties. However, only a few studies are available showing the potential of these marine resources as a source of novel antibiotics that can be used against medically important pathogenic bacteria (Arguelles et al., 2019; Arguelles, 2021). This investigation is the first report in the Philippines regarding antibacterial activities of $U$. prolifera against $S$. epidermidis, Methicillin-resistant $S$. aureus, and P. fluorescens. In addition, this study is the first documented report regarding the antibacterial activity of $U$. prolifera against $P$. fluorescens. These findings suggest that bioactive substances such as polyphenols are present in the seaweed extract, which causes bacterial growth inhibition. Further studies should be done on the purification and identification of these chemical substances to understand the reaction mechanism that causes this biological activity.

\section{Conclusion}

This study presented for the first time in the Philippines the nutritional profile and functional properties of $U$. prolifera. The seaweed showed potent antibacterial activities against bacterial pathogens and potent antioxidant activity that can be exploited for pharmacological use. U. prolifera can produce chemical compounds in high concentration such as carbohydrates, proteins, lipids, and other essential microelements with direct relevance for nutraceutical industries. The potent biological activities and high concentration of important chemical constituents proved the suitability of this seaweed for large-scale production. Using other solvents (such as water, methanol, ethanol, ethyl acetate, and the like) as an extractant is recommended to elucidate further the differences in the biological activities of the extracts. Additional experimental assays are required to know the identity and action mechanism of the bioactive phytoconstituents present in U. prolifera extract and assess the biological activities in vivo.

\section{Acknowledgment}

The authors are thankful for the support given by the Food Laboratory and the Philippine National Collection of Microorganisms (PNCM) of the National Institute of Molecular Biology and Biotechnology (BIOTECH), University of the Philippines Los Baños (UPLB Fund Code: 4700004) for the completion of this study.

\section{References}

Akköz, C., Arslan, D., Unver, A., Özcan, M.M., \& Yilmaz, Y. (2011). Chemical composition, total phenolic and mineral contents of Enteromorpha intestinalis (L.) Kütz and Cladophora glomerata (L.) Kütz seaweeds. Journal of Food Biochemistry, 35(2), 513-523. doi: 10.1111/j.1745-4514. 2010.00399.x.

Alfonso, C., Cardoso, C., Ripol, A., Varela, J., Quental-Ferreira, H., Pousão-Ferreira, P., Ventura, P.S., Delgado, I.M., Coelho, I., Castanheira, I., \& Bandarra, N.M. (2018). Composition and bioaccessibility of elements in green seaweeds from fishpond aquaculture. Food Research International, 105, 271-277. doi:10.1016/j.foodres.2017. 11.015 . 
Alpinar, K., Özyurek, M., Kolak, U., Guclu, K., Aras, Ç., Altun, M., Celik, S.E., Berker, K.I., Bektasoglu, B., \& Ampal, R. (2009). Antioxidant capacities of some food plants wildly grown in Ayvalik of Turkey. Food Science Technology Research, 15(1), 59-64. doi: 10.3136/fstr.15.59.

Alwaleed, E.A. (2019). Biochemical composition and nutraceutical perspectives Red Sea seaweeds. American Journal of Applied Sciences, 16(12), 346-354. doi: 10.3844/ ajassp.2019.346.354.

Association of Official Analytical Chemists (AOAC). (2011). Official methods of analysis of the Association of Official Analytical Chemist. Inc. Washington. DC.

Arguelles, E.D.L.R. (2021). Evaluation of antioxidant capacity, tyrosinase inhibition, and antibacterial activities of brown seaweed, Sargassum ilicifolium (Turner) C. Agardh 1820 for cosmeceutical application. Journal of Fisheries and Environment, 45(1), 64-77.

Arguelles, E.D.L.R., \& Martinez-Goss, M.R. (2021). Lipid accumulation and profiling in microalgae Chlorolobion sp. (BIOTECH 4031) and Chlorella sp. (BIOTECH 4026) during nitrogen starvation for biodiesel production. Journal of Applied Phycology, 33, 1-11. doi: 10.1007/s10811-02002126-z.

Arguelles, E.D.L.R., Monsalud, R.G., \& Sapin, A.B. (2019). Chemical composition and in vitro antioxidant and antibacterial activities of Sargassum vulgare C. Agardh from Lobo, Batangas, Philippines. Journal of the International Society for Southeast Asian Agricultural Sciences (ISSAAS), 25(1), 112-122.

Arguelles, E.D.L.R., Laurena, A.C., Monsalud R.G., \& MartinezGoss, M.R. (2018). Fatty acid profile and fuel-derived physico-chemical properties of biodiesel obtained from an indigenous green microalga, Desmodesmus sp. (I-AU1), as a potential source of renewable lipid and high-quality biodiesel. Journal of Applied Phycology, 30, 411-419. doi: 10.1007/s10811-017-1264-6.

Corsetto, P.A., Montorfano, G., Zava, S., Colombo, I., Ingadottir, B., Jonsdottir, R., Sveinsdottir, K., \& Rizzo, A.M. (2020). Characterization of antioxidant potential of seaweed extracts for enrichment of convenience food. Antioxidants, 9, 249. doi: $10.3390 /$ antiox9030249.

Cotas, J., Leandro, A., Monteiro, P., Pacheco, D., Figueirinha, A., Gonçalves, A.M.M., da Silva, G.J., \& Pereira, L. (2020). Seaweed phenolics: from extraction to applications. Marine Drugs, 18, 384. doi:10.3390/md18080384.

D’Armas, H., Jaramillo, C., D'Armas, M., Echavarría, A. \& Valverde, P. (2019). Proximate composition of several macroalgae from the coast of Salinas Bay, Ecuador. Revista de Biología Tropical, 67(1), 61-68.

El-Sheekh, M.M., Mousa, A.S.H., \& Farghl, A.A.M. (2020). Antibacterial efficacy and phytochemical characterization of some marine brown algal extracts from the red sea, Egypt. Romanian Biotechnological Letters, 25(1), 1160-1169. doi: 10.25083/rbl/25.1/1160.1169.

Gazali, M., Zamani, M.P., \& Nurjanah. (2019). The potency of green algae Chaetomorpha crassa Agardh as antioxidant agent from the coastal of Lhok Bubon, West Aceh. IOP Conference Series: Earth and Environmental Science, 278. doi: 10.1088/ 1755-1315/278/1/012029.

Grina, F., Ullah, Z., Kaplaner, E., Moujahid, A., Eddoha, R., Nasser, B., Terzioglu, P., Yilmaz, M.A., Ertas, A., Öztürk,
M., \& Essamadi, A. (2020). In vitro enzyme inhibitory properties, antioxidant activities, and phytochemical fingerprints of five Moroccan seaweeds. South African Journal of Botany, 128, 152-160. doi:10.1016/j.sajb. 2019. 10.021 .

Guiry, M.D., \& G.M. Guiry. (2020). AlgaeBase. World-wide electronic publication. National University of Ireland, Galway. Retrieved May 9, 2020, from: http:// www.algaebase.org.

Haq, S.H., Al-Ruwaished, G., Al-Mutlaq, M.A., Naji, S.A., AlMogren, M., Al-Rashed, S., Ain, Q.T.,Al-Amro, A.A., \& Al-Mussallam, A. (2019). Antioxidant, anticancer activity and phytochemical analysis of green algae, Chaetomorpha collected from the Arabian Gulf. Scientific Reports, 9, 1-7.

Ismail, G.A. (2017). Biochemical composition of some Egyptian seaweeds with potent nutritive and antioxidant properties. Food Science and Technology, 37(2): 294-302. doi:10.1590/1678-457X.20316.

Jesumani, V., Du, H., Pei, P., Aslam, M., \& Huang, N. (2020). Comparative study on skin protection activity of polyphenol-rich extract and polysaccharide-rich extract from Sargassum vachellianum. PLoS ONE,15(1), e0227308. doi: 10.1371/journal.pone.0227308.

Kordjazi, M., Etemadian, Y., Shabanpour, B., \& Pourashouri, P. (2019). Chemical composition antioxidant and antimicrobial activities of fucoidan extracted from two species of brown seaweeds (Sargassum ilicifolium and Sargassum angustifolium) around Qeshm Island. Iranian Journal of Fisheries Sciences, 18(3), 457-475.

Liu, N.; Fu, X.; Duan, D.; Xu, J.; Gao, X.; Zhao, L. (2018). Evaluation of bioactivity of phenolic compounds from the brown seaweed of Sargassum fusiforme and development of their stable emulsion. Journal of Applied Phycology, 30, 1955-1970. doi: 10.1007/s10811-017-1383-0.

Madkour, F.F., El-Shoubaky, G.A., \& Ebada, M.A. (2019). Antibacterial activity of some seaweeds from the Red Sea coast of Egypt. Egyptian Journal of Aquatic Biology \& Fisheries, 23(2), 265 - 274.

Manandhar, B., Wagle, A., Seong, S.H., Paudel, P., Kim, H.R., Jung, H.A., \& Choi, J.S. (2019). Phlorotannins with potential anti-tyrosinase and antioxidant activity isolated from the marine seaweed Ecklonia stolonifera. Antioxidants, 8, 240. doi:10.3390/antiox8080240.

Matanjun, P., Mohamed, S., Mustapha, N.M., \& Muhammad, K. (2008). Nutrient content of tropical edible seaweeds, Eucheuma cottonii, Caulerpa lentillifera and Sargassum polycystum. Journal of Applied Phycology, 21, 75-80. doi: 10.1007/s10811-008-9326-4.

Mekiniæ, I.G., Skroza, D., Šimat, V., Hamed, I., Èagalj, M., \& Perkoviæ, Z.P. (2019). Phenolic content of brown algae (Pheophyceae) species: extraction, identification, and quantification. Biomolecules, 9, 244. doi: 10.3390/biom 9060244.

Nunes, N., Ferraz, S., Valente, S., Barreto, M.C., \& Pinheiro de Carvalho, M.A.A. (2017). Biochemical composition, nutritional value, and antioxidant properties of seven seaweed species from the Madeira Archipelago. Journal of Applied Phycology, 29(5), 2427-2437. doi: 10.1007/s10811017-1074-x.

Nuñez Selles, A., Castro, H.T.V., Aguero, J.A., Gonzalez, J.G., Naddeo, F., De Simone, F., \& Pastrelli, L. (2002). Isolation 
and quantitative analysis of phenolic antioxidants, free sugars and polyols from mango (Mangifera indica L.) stem bark aqueous decoction used in Cuba as a nutritional supplement. Journal of Agricultural Food Chemistry, 50, 762-766. doi: 10.1021/jf011064b.

Osuna-Ruiz, I., Nieves-Soto, M., Manzano-Sarabia, M.M., Hernández-Garibay, E., Lizardi-Mendoza, J., BurgosHernandez, A., \& Hurtado-Oliva, M.A. (2019). Gross chemical composition, fatty acids, sterols, and pigments in tropical seaweed species off Sinaloa, Mexico. Ciencias Marinas, 45(3), 101-120. doi: 10.7773/cm.v45i3.2974.

Raja, R., Hemaiswarya, S., Sridhar, S., Alagarsamy, A., Ganesan, V., Elumalai, S., \& Carvalho, I. S. (2020). Evaluation of proximate composition, antioxidant properties, and phylogenetic analysis of two edible seaweeds. Smart Science, 1-6. doi: 10.1080/23080477.2020.1795338.

Re, R., Pellegrine, N., Proteggente, A., Pannala, A., Yang, M., \& Rice-Evans, C. (1999). Antioxidant activity applying an improved ABTS radical cation decolorization assay. Free Radical Biology and Medicine, 26, 1231-1237. doi: 10.1016/ S0891-5849(98)00315-3.

Ribeiro, S.M.R., Barbosa, L.C.A., Queiroz, J.H., Knodler, M., $\&$ Schieber, A. (2008). Phenolic compounds and antioxidant capacity of Brazilian mango (Mangifera indica L.) varieties. Food Chemistry, 110 (3), 620-626. doi: 10.1016/j.foodchem. 2008.02.067.

Sameeh, M.Y., Mohamed, A.A., \& Elazzazy, A.M. (2016). Polyphenolic contents and antimicrobial activity of different extracts of Padina boryana Thivy and Enteromorpha sp. marine algae. Journal of Applied Pharmaceutical Science, 6(9), 87-92. doi: 10.7324/JAPS.2016.60913.

Sanger, G., Rarung, L.K., Kaseger, B. E., Assa, J.R., \& Agustin, A.T. (2019). Phenolic content and antioxidant activities of five seaweeds from North Sulawesi, Indonesia. AACL Bioflux, 12(6), 2041-2050.
Senapati, S.R., Singh, C.B., Hassan, M.A., Vignaesh, D., Martin Xavier, K.A., \& Balange, A.K. (2016). Effect of different solvents on total phenolics and antioxidant activity of extracts from Sargassum tenerrium (J. Agardh, 1848). Journal of Environment and Bio-sciences, 30(2), 415-419.

Sivaramakrishnan, T., Swain, S., Saravanan, K., Kiruba, S.R., Roy, S.D., Biswas, L., \& Shalini, B. (2017). In vitro antioxidant and free radical scavenging activity and chemometric approach to reveal their variability in green macroalgae from South Andaman Coast of India. Turkish Journal Fisheries and Aquatic Sciences, 17, 639-648. doi: 10.4194/1303-2712-v17_3_20.

Trono, G.C. Jr. (1997). Field Guide and Atlas of the Seaweed Resources of the Philippines. Manila, Philippines: Bookmark Inc.

Wells, M.L., Potin, P., Craigie, J.S., Raven, J.A., Merchant, S.S., Helliwell, K.E., Smith, A.G., Camire, M.E., \& Brawley, S.H. (2017). Algae as nutritional and functional food sources: Revisiting our understanding. Journal of Applied Phycology, 29, 949-982. doi: 10.1007/s10811-016-0974-5.

Yaich, H., Garna, H., Besbes, S., Paquot, M., Blecker, C., \& Attia, H. (2011). Chemical composition and functional properties of Ulva lactuca seaweed collected in Tunisia. Food Chemistry, 128, 895-901. doi: 10.1016/j.foodchem. 2011.03.114.

Yuan, Y., Zhang, J., Fan, J., Clark, J., Shen, P., Li, Y., \& Zhang, C. (2018). Microwave assisted extraction of phenolic compounds from four economic brown macroalgae species and evaluation of their antioxidant activities and inhibitory effects on a-amylase, a-glucosidase, pancreatic lipase and tyrosinase. Food Research International, 113, 288-297. doi: 10.1016/j.foodres.2018.07.021.

Zhao, C., Yang, C., \& Liu, B. (2016). Biological activities of green macroalgae Enteromorpha prolifera for potential applications. MOJ Food Processing and Technology, 2(5), 153-155. doi: 10.15406/mojfpt.2016.02.00048. 